\title{
Quality of Nursing Courses as Perceived by Students: Relationship with Their Academic Achievement in Palestine College of Nursing
}

\author{
Yousif Mahmoud Awad \\ Faculty of Intermediate Studies, University of Palestine, Gaza Strip, Gaza, Palestine \\ Email: yousif61@yahoo.com
}

Received 28 December 2014; accepted 10 January 2015; published 15 January 2015

Copyright (C) 2015 by author and Scientific Research Publishing Inc.

This work is licensed under the Creative Commons Attribution International License (CC BY). http://creativecommons.org/licenses/by/4.0/

(c) (i) Open Access

\section{Abstract}

The purpose of this study was to determine the Bachelor Science of Nursing (BSN), student's perceptions of the quality of nursing courses taught at Palestine College of Nursing (PCN), which were fundamentals of nursing course, adult nursing course, pediatric nursing course, maternity nursing course, community nursing course, mental health and psychiatric nursing course and nursing management and leadership course, and its relationship with their academic achievement. The Palestine College of Nursing is governmental and Ministry of Health (MOH) affiliated. The sample included 467 nursing students registered in the college who studied the previously mentioned nursing courses. Data were collected using a self-administered questionnaire developed by the researcher, and guided by literature. That was to assess the included nine quality dimensions of the nursing courses as perceived by the students. Content validity and reliability tests were done for the tool. The study revealed that the total students' perceptions of the quality of all nurses courses were within average quality level $(80.42 \%)$. The nursing management course and community health nursing course were of the first two ranks of high quality level $(84.54 \%$, and $\mathbf{8 4 . 4 8 \%}$, respectively), where mental health and psychiatric nursing course, fundamentals of nursing course, adult health nursing course, pediatric nursing course and maternity health nursing course were the next ranks of average quality level. The study revealed that students' perceptions of seven dimensions from nine were with average quality level $(80.50 \%)$. The first rank was the "teacher/instructor characteristics and attributes", dimension of high quality level (84.44\%), while the last rank was "teaching methodology" dimension of average quality level (77.54\%). There was a positive relationship between students' achievement and the courses' quality dimensions, pertaining objectives of the course, contents of the course, teacher/instructor competencies, teacher characteristics, teaching methodology, students/teacher interaction and course evaluation. The study recommended improving the quality of nursing courses for better level and to improve the quality of some dimensions like using different teaching strategies, the quality of clinical settings, and improve the quality of nursing instructors in some clinical areas. Finally the researcher 
recommend for further studies about concerning quality in nursing education.

Keywords

Nursing Education, Quality, Curriculum, Student's Perceptions, Achievement

\section{Introduction}

The goals of education are to prepare people to function properly in society according to societal needs. Quality assurance (QA) is one of the mechanisms developed by educational institutions to ensure that graduates attain adequate standards of education and training. The scope of assessment of QA includes curriculum; student guidance, teaching and assessment; teaching and learning environment; available resources; and standards, quality control and procedures [1].

Curriculum design is one of the exciting intellectual challenges that the field of education can offer. Curriculum design is about what to teach, why to teach it, and how to teach it. At the same times, curriculum design ultimately depends on the purpose of the institution which provides the curricula [2].

The objective of the nursing program is to qualify students to function independently as nurses and to participate in cross-disciplinary cooperation. The education shall give the students skills in theoretical and clinical nursing in accordance with social, scientific and technological developments as well as society's needs for nursing [3].

The quality of nursing and midwifery education could be evaluated by many indicators such as standard curriculum, number of qualified teachers, number of students passing the national examination, number of students receiving a nursing license upon graduation, number of students getting jobs upon graduation, number of research grants and number of publications in peer review journals [1].

Nursing education concentrates on the transmission of nursing knowledge, and assisting nursing students to acquire the necessary skills and attitudes associated with nursing practice. Nursing education encompasses the three domains of learning, the cognitive, affective, and psychomotor. Development of nursing education can be achieved through the evaluation of the effectiveness of teaching in nursing programs [4].

It's founded that in the study entitled "nursing students' perceptions of nursing as a subject and function" [5], the author described students' perceptions of nursing as a theoretical subject and the contents of the subject of nursing include various fields of knowledge. Regarding the function of nursing, students believed there is considerable report writing about which affected their nursing care. The students' perceptions of the contents of the subjects of nursing related only in part to professional function, both at the beginning and the end of their nursing education.

Students' perceptions of effective and ineffective clinical instructors are four categories of important qualities: professional competencies, interpersonal relationship, personality characteristics, and teaching abilities. Moreover, effective teachers have significantly high scores in all of these four qualities. Large differences in scores between effective and ineffective teachers were found in the interpersonal relationship category. Therefore, teachers' attitudes toward students, rather than their professional abilities make crucial difference between effective and ineffective teachers [6].

\subsection{Significance of the Study}

The study is a unique study about the quality of nursing courses as perceived by students that will help to assess the academic nursing staff members in considering the quality factors of nursing courses as perceived by students. Limited studies handle likes this topic in Gaza Strip, there for this study will serve as an exploratory attempt to assess and describe the current situation of students' perceptions about nursing courses and its relations with their academic achievement.

The study results could help initiating change in the faculty regarding the teaching process, clinical practice, clinical setting. Also could help to establish mutual and well-defined expectations among the students and faculty, which could help to create a healthy academic atmosphere conducive to learning. The study will provide an introduction to other research questions in nursing education in Gaza Strip and that will in turn influence the 
future development of the nursing profession in Palestine.

\subsection{Aim of the Study}

The purpose of this study was to determine BSN nursing student's perceptions of the quality of the following nursing courses; fundamentals of nursing, adult nursing, pediatric nursing, maternity nursing, community nursing, mental health and psychiatric nursing and nursing management and leadership taught in Palestine College of Nursing and its relationship with their academic achievement both in theory and clinical.

\subsection{Research Questions}

1) What are the student's perceptions about the quality of their nursing courses?

2) How does the quality of nursing courses correlate with student's achievement?

\section{Subjects and Methods}

\subsection{Study Design}

A descriptive, correlational design was adopted in the current study. This design used to explore the relationship between the student's perceptions of the quality of nursing courses, and its relationship with their academic achievement.

\subsection{Setting of the Study}

The study was conducted in the Palestine College of Nursing at Gaza Strip. The college is a governmental one affiliated to the Ministry of Health.

\subsection{Sample and Sampling Technique}

A lists of academic numbers for all nursing students whom registered, attended the courses and the final exam according to the study curriculum plan were obtained from the admission and registration department in the Palestine College of Nursing.

Study sample was non probability quota sample from total student number (600) students whom formerly registered in the college. The sample size was (467), nursing students studied previously mentioned nursing courses distributed as the following: first level, 74 students; second level, 70 students; third level, 119 students; fourth level, 171 students; and upgrading students 33 students.

\subsection{Inclusion Criteria}

Students who studied the above mentioned nursing courses during the first and second semesters both theory and practice were included in the study.

\subsection{Tools of the Study}

Data was collected using two tools, the first tool was a self-administered questionnaire developed by the researcher after review of the literature. The tool included nine domains "Objectives of the course, Contents of the course, Teacher/Instructor competencies, Teacher/Instructors attributes, characteristics”, Teaching Methodology, Students/teacher Interaction \& Communication, Courses Evaluation Process "Exams, Grading/Assignment, Courses Evaluation Process” Exams, Grading/Assignment, The Clinical Instructors, and Clinical Setting “domains of total 87 questions of five points Likert's scale measured the quality of nursing courses as perceived by the students. The tool covered three main parts.

The second tool was the achievement sheet, which included student's academic number, study level, semester, study year and students grades/marks for each nursing course included in this study both in theory and clinical.

\subsection{Scoring the Quality of Perceptions}

For the purpose of this study students' perceptions of the quality of nursing courses have been classified into three scoring quality levels according to the following: high level ( $>4.25$ mean score, $\geq 85 \%$ ), average level 
range from (3.5 - 4.25 mean score, = 70\% - 85\%), and low quality level $(<3.5$ mean score, $\leq 70 \%)$.

\subsection{Content Validity}

Content validity was checked before the pilot study and the actual data collection, through distribution of the first tool to nine experts in the field of the study, to ensure appropriateness, relevancy, clarity and completeness of the tool. Most of the tool items had consensus from the group of experts. Modifications and changes were introduced as required.

\subsection{Reliability}

Reliability was measured by using Alpha Chronbach Coefficient of total (87) questions which was equal to (0.972).

\subsection{Ethical Consideration}

Acceptance of all students to participate in this study were obtained and ensured their participation was voluntarily. Students were assured that anonymity and confidentiality was maintained and the information they provided would be used only for the purpose of this research. Any students have the right to participate, refuse or withdraw from the study at any time without any conditions or threatening.

A written approval was obtained from the $\mathrm{MOH}$ officials in Gaza Strip to conduct the research, because the college is one of the MOH institutions.

\subsection{Data Analysis and Statistical Design}

Data entry performed by using the Statistical Package for Social Sciences(SPSS) software version 16, and then data cleaning were done. Quantitative data were expressed in measures of central tendency like mean, Standard Deviation (SD); and categorical data were expressed in terms of frequency and percent. t-test was used for comparison between numerical variables, one way analysis of variance (ANOVA), and correlation tests was used for comparison between categorical variables. A significance level was considered when P value 0.05 .

\section{Results}

Results of the current study are presented as the following sequence, demographic characteristics of the students, students perceptions of the quality dimensions of all nursing courses, students perceptions of the quality of all nursing courses, correlation between students achievements, and quality dimensions of nursing courses, and t-test to differentiate between students gender perceptions of the quality dimensions of nursing courses.

\subsection{Demographic characteristics of the students}

Table 1 shows that $50.3 \%$ of the students were males, while $49.7 \%$ were females. The age range of $47.8 \%$ was 20 - 22 years. The highest percentage $36.6 \%$ of the students were enrolled in the fourth level, while the lowest percentage $7.1 \%$ were the students in the upgrading program. The students enrolled in the first semester represented $41.1 \%$, while the enrolled in the second semester were $58.9 \%$.

\subsection{Student's Perceptions of the of the Quality Dimensions of All Nursing Courses}

Table 2 shows that the total students perceptions of the quality dimensions for all nurses courses was with average level (mean $=4.025$ ), students perceived the dimensions, teacher/instructors attributes/characteristics, the clinical Instructors and teacher/instructor competencies, of this course were with average quality level and of the first ranks with (mean $=4.221,4.134$, and 4.121 , respectively). Where they perceived the dimensions, teaching methodology and contents of the course, of the least ranks of the quality level (mean $=3.876$ and 3.935, respectively).

\subsection{Total Students Perceptions of the Quality of All Nursing Course}

Table 3 shows that the total perceptions of quality level of all nursing courses in this study were with average 
Table 1. Demographic characteristics of the students by gender, age groups, study levels and nursing courses $(n=467)$.

Items $\quad$ Frequency $\quad$ Percent \%

\section{1) Gender}

$\begin{array}{lcc}\text { Male } & 235 & 50.3 \\ \text { Female } & 232 & 49.7 \\ \text { Total } & \mathbf{4 6 7} & \mathbf{1 0 0 \%}\end{array}$

2) Age Groups

$\begin{array}{ccc}<20 \text { years } & 101 & 21.6 \\ 20-22 \text { years } & 223 & 47.8 \\ 22.1 \text { - 24 years } & 109 & 23.3 \\ >24 \text { years } & 34 & 7.3 \\ \text { Total } & \mathbf{4 6 7} & \mathbf{1 0 0 \%}\end{array}$

3) Number of Students in Different Study Levels

$\begin{array}{ccc}\text { First Level } & 74 & 15.8 \\ \text { Second Level } & 70 & 15 \\ \text { Third Level } & 119 & 25.5 \\ \text { Fourth Level } & 171 & 36.6 \\ \text { Upgrading Programs } & 33 & 7.1 \\ \quad \text { Total } & \mathbf{4 6 7} & \mathbf{1 0 0 \%}\end{array}$

4) Study Semester/Nursing Courses

- First Semester

$\begin{array}{cccc}\text { Community Health Nursing } & 70 & 15 & \\ \text { Mental and Psychiatric Nursing } & 51 & 10.9 & 41.1 \% \\ \text { Maternity Health Nursing } & 71 & 15.2 & \end{array}$

- Second Semester

\begin{tabular}{cccc} 
Nursing Management & 79 & 16.9 & \\
Adult Health Nursing & 74 & 15.9 & \\
Pediatric Nursing & 70 & 15 & $58.9 \%$ \\
Fundamentals of Nursing & 52 & 11.1 & \\
Total for Each Category & $\mathbf{4 6 7}$ & $\mathbf{1 0 0 \%}$ \\
\hline
\end{tabular}


Table 2. Total student's mean perceptions by the quality dimensions of all nursing courses $(n=467)$.

\begin{tabular}{|c|c|c|c|c|c|c|c|}
\hline No. & Quality of the Course Dimensions & $\begin{array}{l}\text { No. of } \\
\text { Items }\end{array}$ & Sum & $\begin{array}{l}\text { Maxi. Mean } \\
\text { Score (5) }\end{array}$ & $\pm \mathrm{SD}$ & $\%$ & Rank \\
\hline 1 & Teacher/Instructors Attributes “Characteristics” & 11 & 21688 & 4.221 & 6.350 & 84.44 & 1 \\
\hline 2 & The Clinical Instructors & 7 & 12648 & 4.134 & 5.860 & 82.69 & 2 \\
\hline 3 & Teacher/Instructor Competencies & 12 & 23099 & 4.121 & 7.796 & 82.44 & 3 \\
\hline 4 & Courses Evaluation Process “Exams, Grading/Assignment” & 14 & 26921 & 4.117 & 7.153 & 82.35 & 4 \\
\hline 5 & Students/Teacher Interaction and Communication & 8 & 15220 & 4.073 & 4.792 & 81.48 & 5 \\
\hline 6 & Objectives of the Course & 6 & 11402 & 4.069 & 4.034 & 81.38 & 6 \\
\hline 7 & Clinical Setting & 6 & 10539 & 4.019 & 4.506 & 80.39 & 7 \\
\hline 8 & Contents of the course & 14 & 25729 & 3.935 & 7.646 & 78.71 & 8 \\
\hline \multirow[t]{2}{*}{9} & Teaching Methodology & 9 & 16294 & 3.876 & 6.920 & 77.54 & 9 \\
\hline & Total & 87 & 163540 & 4.025 & 43.85 & 80.50 & \\
\hline
\end{tabular}

Table 3. Student's mean perceptions by the ranking of the quality of nursing courses $(n=467)$.

\begin{tabular}{cccccc}
\hline No. & Nursing courses & No. of Subjects & Maxi. Mean Score (5) & $\%$ & Rank \\
\hline 1 & Nursing Management & 79 & 4.227 & 84.54 & 1 \\
2 & Community Health Nursing & 70 & 4.224 & 84.48 & 2 \\
3 & Mental Health and Psychiatric Nursing & 51 & 4.169 & 83.38 & 3 \\
4 & Fundamental of Nursing & 74 & 4.077 & 81.54 & 4 \\
5 & Adult Health Nursing & 70 & 3.965 & 79.30 & 5 \\
6 & Pediatric Nursing & 52 & 3.874 & 77.48 & 6 \\
7 & Maternity Nursing & 71 & 3.615 & 72.30 & 7 \\
\hline
\end{tabular}

quality level (mean $=4.021)$. Students perceived the nursing management course, and community health nursing with high quality level (mean $=4.227$, and 4.224 , respectively) and of the first ranks. They perceived the pediatric nursing course and maternity nursing course with average quality level (mean $=3.874$, and 3.615 , respectively), and of the least ranks of the nursing courses.

\subsection{Students Achievements}

Table 4 shows that the students' grades levels were excellent level, for $13.1 \%$, very good level, for $35.3 \%$, good level for $34 \%$, and the average, for $17.6 \%$. The highest clinical grade level $82.9 \%$, were very good level, excellent level $16.5 \%$, while only $0.6 \%$ of the students have got good grade level.

Table 5 shows that there was a strong positive significant correlation between the quality of nursing courses dimensions and students' academic achievement in the theoretical part with all dimensions of all nursing courses and total score for all courses except the dimensions, the clinical instructors and clinical setting where there is no statistical significant correlation observed. 
Table 4. Distribution of students according their academic achievement in theory and practice $(\mathrm{n}=467)$.

\begin{tabular}{|c|c|c|}
\hline Grades Levels “Theory” & Frequency & Percent \% \\
\hline Excellent (90\% - 100\%) & 61 & 13.1 \\
\hline Very good (80\% - 89\%) & 165 & 35.3 \\
\hline Good (70\% - 79\%) & 159 & 34.0 \\
\hline Average (60\% - 69\%) & 82 & 17.6 \\
\hline Total & 467 & 100 \\
\hline Grades Levels “Clinical” & Frequency & Percent \% \\
\hline Excellent (90\% - 100\%) & 77 & 16.5 \\
\hline Very good (80\% - 89\%) & 387 & 82.9 \\
\hline Good (70\% - 79\%) & 3 & 0.6 \\
\hline Average (60\% - 69\%) & 0 & 0 \\
\hline Total & 467 & 100 \\
\hline
\end{tabular}

Table 5. Correlation level between the quality dimensions of nursing courses and students' academic achievements ( $\mathrm{n}=$ 467).

\begin{tabular}{|c|c|c|c|}
\hline No. & Quality of the Course Dimensions & Correlation Level (r value) & Sig. Level \\
\hline 1 & Objectives of the Course & ${ }^{* *} 0.208$ & $(0.01)$ \\
\hline 2 & Contents of the Course & ${ }^{* *} 0.149$ & $(0.01)$ \\
\hline 3 & Teacher/Instructor Competencies & ${ }^{*} 0.094$ & $(0.05)$ \\
\hline 4 & Teacher/Instructors Attributes “Characteristics” & ${ }^{* *} 0.143$ & $(0.01)$ \\
\hline 5 & Teaching Methodology & ${ }^{*} 0.092$ & $(0.05)$ \\
\hline 6 & Students/Teacher Interaction and Communication & *** 0.166 & $(0.01)$ \\
\hline 7 & Courses Evaluation Process "Exams, Grading/Assignment” & ${ }^{* *} 0.177$ & $(0.01)$ \\
\hline 8 & The Clinical Instructors & 0.070 & Not Sig. \\
\hline 9 & Clinical Setting & 0.000 & Not Sig. \\
\hline & Total & ${ }^{* *} 0.138$ & Sig. at $(0.01)$ \\
\hline
\end{tabular}

r value at df (465) and sig. level $(0.05)=0.088$ (2-tailed); $r$ value at df (465) and sig. level $(0.01)=0.115$ (2-tailed).

Table 6 shows that there is a statistical, significant different, between students' achievements levels, and their perceptions of the quality dimensions number $(1,2,4,6,7$ and the total scores) at sig. level $(0.001,0.002,0.016$, 0.026, 0.001 , and 0.033 , respectively). While there is no statistical significant difference of students, achievement levels of their perceptions of the quality dimensions numbers (3, 5, 8 and 9).

Table 7 reveal that there is no statistical significance difference between gender of all domains except in total score there is statistical significance difference $(0.012)$ towards female students. 
Table 6. Analysis of the variance in the mean scores of students achievements levels of perceptions of the quality of the different dimensions of the components of nursing courses, (ANOVA, test), ( $\mathrm{N}=467)$.

\begin{tabular}{|c|c|c|c|c|}
\hline Quality of the Course Dimensions & Source of Variance & Mean Square & f & Sig. \\
\hline & Between Groups & 110.013 & & \\
\hline \multirow[t]{3}{*}{ 1) Objectives of the Course } & Within Groups & 15.666 & 7.022 & 0.001 \\
\hline & Total & & & \\
\hline & Between Groups & 278.798 & & \\
\hline \multirow[t]{3}{*}{ 2) Contents of the Course } & Within Groups & 57.040 & 4.888 & 0.002 \\
\hline & Total & & & \\
\hline & Between Groups & 68.518 & & \\
\hline \multirow[t]{3}{*}{ 3) Teacher/Instructor Competencies } & Within Groups & 60.723 & 1.128 & 0.337 \\
\hline & Total & & & \\
\hline & Between Groups & 137.103 & & \\
\hline \multirow[t]{3}{*}{$\begin{array}{l}\text { 4) Teacher/Instructors Attributes } \\
\text { "Characteristics" }\end{array}$} & Within Groups & 39.697 & 3.454 & 0.016 \\
\hline & Total & & & \\
\hline & Between Groups & 69.964 & & \\
\hline \multirow[t]{3}{*}{ 5) Teaching Methodology } & Within Groups & 47.740 & 1.466 & 0.223 \\
\hline & Total & & & \\
\hline & Between Groups & 70.804 & & \\
\hline \multirow[t]{3}{*}{$\begin{array}{l}\text { 6) Students/Teacher Interaction \& } \\
\text { Communication }\end{array}$} & Within Groups & 22.658 & 3.125 & 0.026 \\
\hline & Total & & & \\
\hline & Between Groups & 295.939 & & \\
\hline \multirow{3}{*}{$\begin{array}{l}\text { 7) Courses Evaluation, Exams, } \\
\text { grading/Assignment }\end{array}$} & Within Groups & 49.579 & 5.969 & 0.001 \\
\hline & Total & & & \\
\hline & Between Groups & 54.002 & & \\
\hline \multirow[t]{3}{*}{ 8) The Clinical Instructors } & Within Groups & 34.202 & 1.579 & 0.194 \\
\hline & Total & & & \\
\hline & Between Groups & 43.533 & & \\
\hline \multirow[t]{3}{*}{ 9) Clinical Setting } & Within Groups & 20.140 & 2.162 & 0.092 \\
\hline & Total & & & \\
\hline & Between Groups & 5583.193 & & \\
\hline Total & Within Groups & 1899.579 & 2.939 & 0.033 \\
\hline
\end{tabular}

“F” table value at $(3,466) \mathrm{d}$ f. at $(0.05)$ sig. level equal 2.62; "F” table value at $(3,466) \mathrm{d}$ f. at $(0.01)$ sig. level equal 3.83. 
Table 7. t. test independent sample results of comparison between gender with all domains of the study.

\begin{tabular}{|c|c|c|c|c|c|c|c|}
\hline No. & Domains & Group & $\mathrm{N}$ & Mean & SD & t. & Sig. Value \\
\hline \multirow{3}{*}{1} & \multirow{3}{*}{ Objectives of the Course } & Male & 235 & 24.272 & 4.263 & \multirow{3}{*}{0.771} & \multirow{3}{*}{0.441} \\
\hline & & & & & & & \\
\hline & & Female & 232 & 24.560 & 3.792 & & \\
\hline \multirow{3}{*}{2} & \multirow{3}{*}{ Contents of the Course } & Male & 235 & 54.723 & 8.063 & \multirow{3}{*}{1.055} & \multirow{3}{*}{0.292} \\
\hline & & & & & & & \\
\hline & & Female & 232 & 55.470 & 7.198 & & \\
\hline \multirow{3}{*}{3} & \multirow{3}{*}{ Teacher/Instructor Competencies } & Male & 235 & 49.055 & 8.049 & \multirow{3}{*}{1.136} & \multirow{3}{*}{0.256} \\
\hline & & & & & & & \\
\hline & & Female & 232 & 49.875 & 7.525 & & \\
\hline \multirow{2}{*}{4} & \multirow{2}{*}{$\begin{array}{l}\text { Teacher/Instructors Attributes } \\
\text { "Characteristics" }\end{array}$} & Male & 235 & 46.438 & 6.471 & \multirow{2}{*}{0.010} & \multirow{2}{*}{0.992} \\
\hline & & Female & 232 & 46.444 & 6.240 & & \\
\hline \multirow{3}{*}{5} & \multirow{3}{*}{ Teaching Methodology } & Male & 235 & 34.502 & 6.687 & \multirow{3}{*}{1.222} & \multirow{3}{*}{0.222} \\
\hline & & & & & & & \\
\hline & & Female & 232 & 35.284 & 7.140 & & \\
\hline \multirow{2}{*}{6} & \multirow{2}{*}{$\begin{array}{l}\text { Students/Teacher Interaction and } \\
\text { Communication }\end{array}$} & Male & 235 & 32.349 & 5.061 & \multirow{2}{*}{1.099} & \multirow{2}{*}{0.272} \\
\hline & & Female & 232 & 32.836 & 4.502 & & \\
\hline \multirow{2}{*}{7} & \multirow{2}{*}{$\begin{array}{l}\text { Courses Evaluation Process } \\
\text { "Exams, Grading/Assignment" }\end{array}$} & Male & 235 & 57.277 & 7.426 & \multirow{2}{*}{1.126} & \multirow{2}{*}{0.261} \\
\hline & & Female & 232 & 58.022 & 6.861 & & \\
\hline \multirow{3}{*}{8} & \multirow{3}{*}{ The Clinical Instructors } & Male & 205 & 29.098 & 5.506 & \multirow{3}{*}{0.519} & \\
\hline & & & & & & & 0.604 \\
\hline & & Female & 232 & 28.806 & 6.165 & & \\
\hline & & Male & 205 & 24.224 & 4.430 & & \\
\hline 9 & Clinical Setting & & & & & 0.469 & 0.639 \\
\hline & & Female & 232 & 24.022 & 4.579 & & \\
\hline & & Male & 235 & 345.132 & 46.598 & & \\
\hline & Total & & & & & 2.524 & 0.012 \\
\hline & & Female & 232 & 355.319 & 40.347 & & \\
\hline
\end{tabular}

“"” table value at (465) d f. at (0.05) sig. level equal 1.96 .

\section{Discussion}

The present study was conducted to determine BSN, nursing student's perceptions of the quality of the nursing courses in the Palestine college of nursing this included; fundamentals of nursing, adult nursing, pediatric nursing, maternity nursing, community nursing, mental and psychiatric health nursing and nursing management and leadership taught in Palestine College of Nursing and its relationship with their academic achievement.

\subsection{Demographic Characteristics}

According to the study findings the demographic characteristics of the students, revealed that the gender distribution approximately had the same percent. The Palestine College of Nursing accepts each year students of both genders, who have general secondary school education. Then they are classified into male and female classes.

This could be because the college started to admit both sexes in nursing education because the Palestinian community has a need to appoint graduates from both sexes in different health settings. This is in contrary of what was been carried out before those male nurses were dominating. This consistent with the results of [7] who 
reported that increasing the number of male nurses was a community aim as in such a nursing college mostly admit female nursing students were dominating.

Student's age rang was from $<20$ years to $>24$ years. About fifty percent of students age were ranged from 20 22 years, this may be the college majority of the students were regular and normally upgrading.

\subsection{Students' Perceptions of the Quality Dimensions of All Nursing Courses}

The study revealed that, students at the Palestine College of Nursing perceived the nursing courses as having average quality level (80.50\%), with some variation between dimensions where the dimensions "teacher attributes" and "the clinical instructor" having the highest scores, (84.44\% 82.69\% respectively). This could be because the college appoints teachers according to criteria, which assures their competency and consequently the quality of the teaching-learning process. The students perceived their instructors as having good personal and professional characteristics as dealing with students with respect, giving feedback, motivating them, being available most of the times answering their questions, giving instructions, create a positive and comfortable learning environment, correlating theory with practice in clinical settings and show good role model.

The study findings was supported by many researchers, [8], reported that the most important characteristics of effective teacher/instructor was personality qualities and traits which emerged as the highest ranking as corrects students mistakes without criticizing them, were available, well prepared for teaching, a good role model, and encouraged a climate of mutual respect. [9] added that students perceived effective teacher as the one who teach at the student knowledge level, and provide frequent feedback to them. Also [9] reported that good teachers create positive relationships with students, are professional role models, and provide students with interpersonal support.

Generally, teaching methodology have been perceived by students as having the least quality level score (77.54\%), of the dimensions of all nursing courses. This could be because most of teachers using a limited strategies and methods of teaching, as they depended on lectures, and power points presentations only. Other teaching methods like role play, group discussions, problem solving, simulations, self-learning...etc. were not used because of the unavailability of facilities, both manpower and materials.

These results were not congruent with the results of previous researchers. [10] found that undergraduate students perceived teaching strategies, faculty enthusiasm and knowledge base, faculty support of students efforts are faculty strengths points. Also [9] found that teaching methods was chosen by students as the next most frequent characteristics of effective teacher/instructor after personality attributes.

The study findings revealed that there is no statistical significant difference between students' gender and their perceptions of the quality dimensions of all courses, except in the total score there is a statistical significant difference at sig. level (0.012). This could be because the students males and females are from the same culture, background, nursing courses were taught by the same teacher, same contents, they did clinical practice in the same settings, and taken the same exams and assignment.

The study results supported by other researchers, [11], who reported in this study entitled "classroom and clinical learning approach on academic achievement associated degree nursing students" there was no significant difference between the learning outcomes and the students gender. [12] added that gender is not associated with students' academic success rate. Other study [13], found that there is no statistical significant difference between male and female students in their perception of effective teacher regarding professional competencies, interpersonal relationship and personal characteristics.

\subsection{Students Perceptions of the Overall Quality Level of All Nursing Courses}

The study findings revealed that the students perceived the whole nursing courses as having average quality level (80.42\%). While there is, some differences of scores. among nursing courses The "nursing management course, and community health nursing course" were of the first two ranks and having high quality level (84.54\% and $84.48 \%$, respectively), Mental health and psychiatric nursing course, fundamentals of nursing course, adult health nursing; pediatric nursing, and maternity nursing were of next ranking respectively with scores (83.38\%, 81.34\%, 97.30\%, 77.48\%, and 72.30\%, respectively).

This may be because the first two courses was taught for students at the fourth level, where the students have higher expectations, maturity, more experience, and more knowledge and can assess and evaluate matters better than lower levels. Other factors could the quality of teachers/instructors, contents taught, and teachers/instruc- 
tors interactions. This result is consistent with [14], who found that students of upper level classes evaluate their instructors with higher ratings scores.

\subsection{Students Achievement Levels "Theory and Clinical"}

The study results revealed that students' grades in the theoretical part of the course were ranged from average level, (60\% - 69\%), to the excellent levels, (90\% - 100\%), with grades mean score $78.53 \%$. The excellent level was $13.1 \%$, very good level was $35.5 \%$, good level was $34 \%$, and average level was $17.6 \%$, of the study sample.

This could be because the theoretical grades were obtained through year work such as many tests during the semester, as quizzes, midterm, writing assignments, attendance, participation and final exam; through this process many grades may be lost. Another cause may be due to difficult exams, and students stress. What mentioned may affect the students' final theoretical achievement levels. This is consistent with [15], who reported that nursing educators can use many assessment strategies for given course like doing tests, assignments, quizzes, projects, presentations and contribution to discussions.

Students' clinical achievements were ranged from good level (70\% - 79\%), to excellent level (80\% - 89\%), with grades mean score, (86.85\%). The excellent level was $16.5 \%$, very good level was $82.9 \%$, and good level was $0.06 \%$, of the study sample. This is not congruent with [11], who reported about classroom and clinical learning approach on academic achievement, the sample mean score in clinical performance grade was (78.8\%).

This could be because the students in clinical settings deals with many cases with different medical diagnosis, practiced and oriented to different nursing models of care delivery such as, total patient care, case management, functional nursing, methods, and team nursing tried to do their best efforts to integrate theory into practice, also they are facing the real situations in clinical settings and they have to get involved and take the opportunity in the practice and express themselves to acquire skills and knowledge. Another factor is that the instructor and working staff guide the students to practice and acquire more skills during their presence in the clinical settings.

In the same context the clinical achievement of very good level was constitutes (82.9\%), of study sample which is too high in comparison with theoretical grades where only (35.3\%), have very good level with ratio (2.4:1). This may lead to grade inflation, which could be happen because most of clinical instructors are part timers, did not observe the students adequately and consequently over estimate them. This is consistent with [16], who reported that many nursing students are evaluated by seasonal, term, and part-time faculty. This could be a significant contributing factor to grade inflation.

On the same domain, [15], reported that evaluating nursing students in the clinical practice is a complex process and little is known about how educators assess students learning and competencies in clinical settings.

\subsection{Relationship between the Quality Dimensions of the Nursing Courses and Students' Achievements}

There is a significant positive relationship between the quality dimensions of the nursing courses and the students' achievements. This relationship was found between students' achievements and the following quality dimensions such as explaining objectives of the course at the beginning of the course, the contents of the course, teacher characteristics, students/teacher interaction, course evaluation, teacher competencies, and teaching methodology and students' achievements.

This could be because the courses objectives, were clear, logic, explained at the beginning of the course and relevant to the course topics, courses contents were interested, covered all topics and subjects of the course and delivered in a way that convenient to students, satisfactory courses evaluation process, fair evaluation, comprehensive exams and covered most of the course topics, teachers were competencies, efficient and well prepared. Where students' achievements reflect their understanding and knowledge acquired through course taught. This is in agreement with [17], who reported that grades provide students with information related to how well they understand course material.

This is consistent with [4], who reported that the perceptions of Iranian nurse educators and students regarding the teaching effectiveness in university-based program identified specific teacher behaviors that contribute to student's achievements, and recommended better and more comprehensive measures of teaching effectiveness to be developed. Also at the same context this is consistent with [18], who examined that relationship between university nursing students classroom management activities and academic performance, the findings revealed that there is a statistically significant relationship with the course grade was revealed at significance level $(\mathrm{p}<$ 
$0.05)$ level.

Also the study revealed that there is a statistical significant difference between students' achievements level of their total perceptions of all nursing courses, and five dimensions from nine. These are the objectives of the course, contents of the course, teacher/instructors characteristics, students/teacher interaction and communication, and courses evaluation

\subsection{Study Implication for Nurse Educators}

Academic program integrity is meant of control quality in nursing education. Higher education is delivered via program or courses leading to academic or professional awards, with each program having a nursing educators team responsible for its operational management. Curriculum quality criteria should be related to present and anticipated future needs, aims and objectives which are explicit and carefully focused.

The study results could help initiating change in the faculty staff regarding the teaching process, teaching methods, clinical practice, clinical setting and students evaluation.Also could help to establish mutual and welldefined expectations among the students and faculty administrators and academic staff, which could help to create a healthy academic atmosphere conducive to learning.

\section{Conclusion and Recommendations}

The study concluded that the students' total perceptions of the quality of nursing courses were of average quality level and there is a significant correlation between most of the courses' quality dimensions and students' academic achievement.

The study recommended improving the quality of nursing courses for better level and to improve the quality of some dimensions like using a diversity of teaching strategies, the quality of clinical settings, clinical environment, and improve the quality of nursing instructors in some clinical areas.

\section{Recommendations}

According to the results of the current study, the following recommendations are suggested:

- The Palestine College of Nursing should encourage different teaching strategies such as self-directed learning, problem-solving skills, role play, simulation, group discussions and ensure its application, especially for the pedantic nursing course, adult health nursing course, maternity health nursing course, fundamentals of nursing and mental and psychiatric nursing course.

- Improve the readiness of clinical settings for clinical practice such as enough facilities, supplies and equipment to enable nursing students to practice what they have learned in the classroom safely and efficiently, especially for the mental health and psychiatric, and maternity training clinical settings.

- Improve the clinical nursing instructors' abilities and potentials in supervision, communication and evaluation skills, through refreshment courses about clinical learning strategies especially for community health nursing and maternity health nursing courses.

- Contents of the nursing courses to be organized in a logic sequence, containing important issues which are relevant to students' career practice.

\section{References}

[1] WHO (2007) Quality Assurance and Accreditation of Nursing and Midwifery Educational Institutions. Report of Regional Workshop, Malé, Maldives, South East Asia, 9-11 July 2007.

[2] Iwasiw, C., Goldenberg, D. and Andrusyszyn, M. (2008) Curriculum Development in Nursing Education. 2nd Edition, Illustrated, Jones and Bartlett Publisher, Sudbury, MA.

[3] Bydam, J. (2004) Bachelor of Nursing Curriculum, Copenhagen County School of Nursing and Radiography. Canadian Association of Schools of Nursing, The CASN Accreditation Program, Ottawa.

[4] Salsali, M. (2005) Evaluating Teaching Effectiveness in Nursing Education. An Iranian Perspective. BMC Medical Education, 5, 29. http://dx.doi.org/10.1186/1472-6920-5-29

[5] Granum, V. (2004) Nursing Students' Perceptions of Nursing as a Subject and a Function. Journal of Nursing Education, 43, 297-304.

[6] Tang, F., Chou, S. and Chiang, H. (2005) Students’ Perceptions of Effective and Ineffective Clinical Instructors. Jour- 
nal of Nursing Education, 44, 187-192.

[7] Ozdemir, A., Akansel, N. and Tunk, G.C. (2008) Gender and Career: Female and Male Nursing Students' Perceptions of Mail Nursing Role in Turkey. Health Science Journal, 2, 153-161.

[8] Sieh, S. and Bell, S. (1994) Perceptions of Effective Clinical Teachers in Associate Degree Programs. Journal of Nursing Education, 33, 389-394.

[9] Berg, C.L. and Lindseth, G., (2004) Students' Perspectives of Effective and Ineffective Nursing Instructors. Journal of Nursing Education, 43, 565-568.

[10] Wolf, A., Bender, P., Beitz, J., Wieland, D. and Vito, K. (2004) Strengths and Weaknesses of Faculty Teaching Performance Reported by Undergraduate and Graduate Nursing Students. Journal of Professional Nursing, 20, 118-128. http://dx.doi.org/10.1016/j.profnurs.2004.03.003

[11] Carrick, J. (2010) The Effect of Classroom and Clinical Learning Approach on Academic Achievement Associated Degree Nursing Students. Indiana University of Pennsylvania, Indiana.

[12] Dante, A., Valoppi, G., Saiani, L. and Palese, A. (2011) Factors Associated with Nursing Students’ Academic Success or Failure: A Retrospective Italian Multicenter Study. Nurse Education Today, 31, 59-64. http://dx.doi.org/10.1016/j.nedt.2010.03.016

[13] Nahas, V. and Yam, B. (2001) Hong Kong Nursing Students' Perceptions of Effective Clinical Teachers. Journal of Nursing Education, 40, 233-237.

[14] Smith, H. and Nortvedt, M. (2008) Evaluation of Evidence-Based Methods Used to Teach Nursing Students to Critically Appraise Evidence. Journal of Nursing Education, 47, 372-375. http://dx.doi.org/10.3928/01484834-20080801-08

[15] Oermann, M., Saewert, K., Charasika, M. and Yarbrough, S. (2009) Assessment and Grading Practice in School of Nursing: National Survey Finding Part I. Nursing Education Perspective, 30, 274-278.

[16] Scanlan, J. and Care, W. (2004) Grade Inflation: Should We Be Concerned? Journal of Nursing Education, 43, 475478.

[17] Marzano, R. (2000) Transforming Classroom Grading. Association for Supervision and Curriculum Development, Alexandria.

[18] Reyes, H.L. (2007) The Relationship between University Nursing Students Classroom Management Activities and Academic Performance. Unpublished Thesis. 
Scientific Research Publishing (SCIRP) is one of the largest Open Access journal publishers. It is currently publishing more than 200 open access, online, peer-reviewed journals covering a wide range of academic disciplines. SCIRP serves the worldwide academic communities and contributes to the progress and application of science with its publication.

Other selected journals from SCIRP are listed as below. Submit your manuscript to us via either submit@scirp.org or Online Submission Portal.
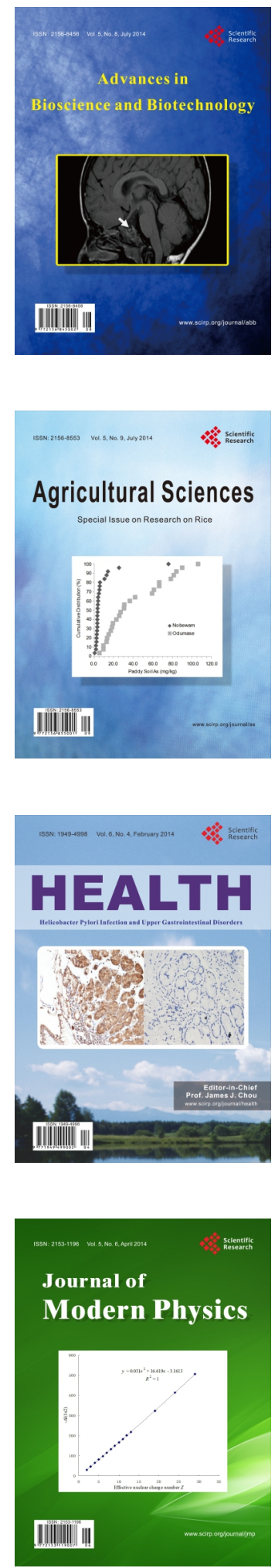
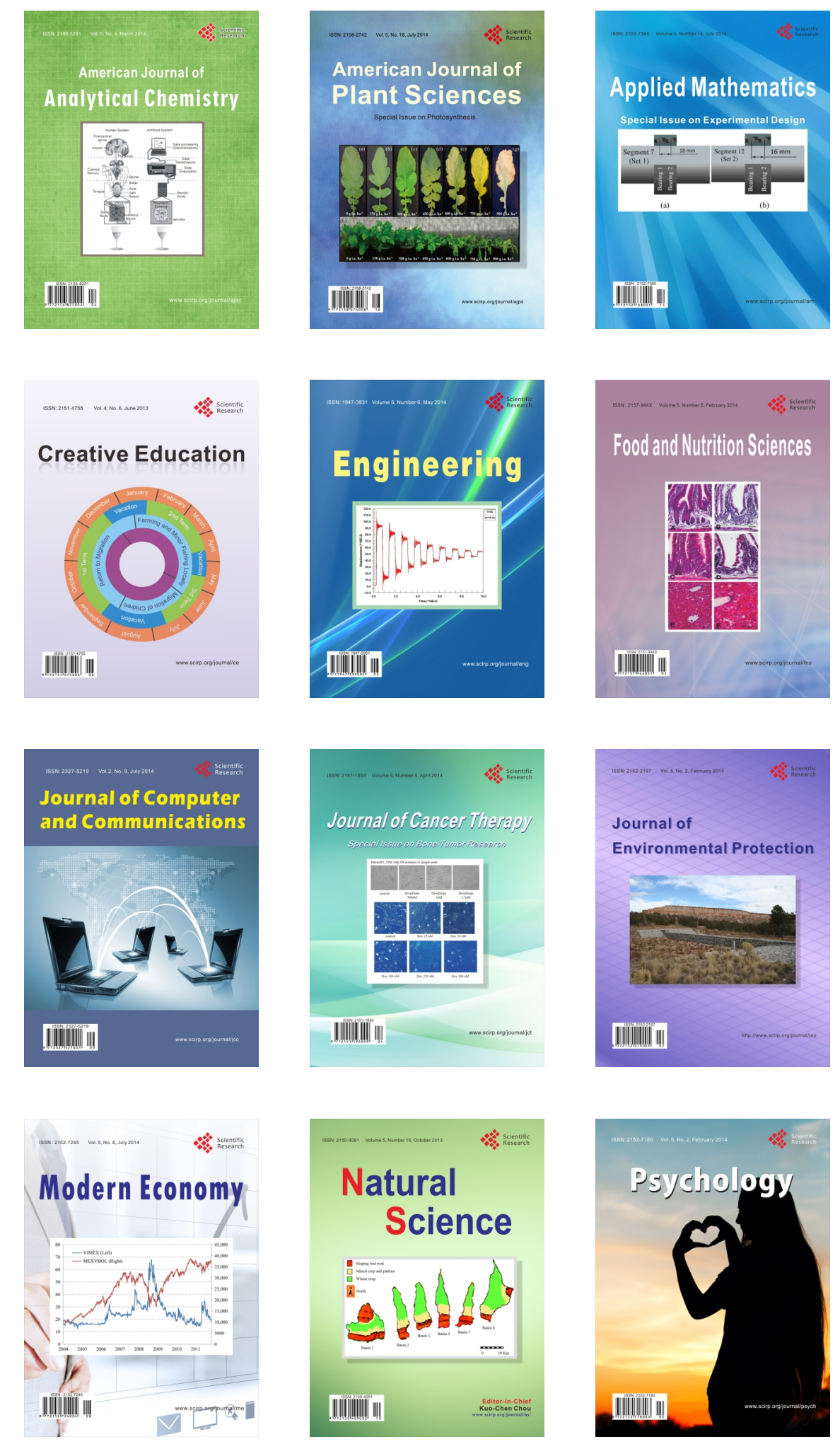